ISSN 0258-7122

Bangladesh J. Agril. Res. 38(3): 523-529, September 2013

\title{
PERFORMANCE OF DIFFERENT CROP SPECIES WITH POINTED GOURD (Trichosanthes dioica Roxb.)
}

\author{
M. S. ALOM ${ }^{1}$, B. L. NAG ${ }^{2}$, M. N. ISLAM ${ }^{1}$, F. AHMED ${ }^{3}$ AND S. AKTHER ${ }^{4}$
}

\begin{abstract}
The experiment was conducted at the Regional Agricultural Research Station, Jessore during the period from November 2008 to April 2010 to find out the suitable component crop and planting system under intercropping system with pointed gourd for higher yield and economic return. The treatment combinations were $\mathrm{T}_{1}=$ Pointed gourd $(\mathrm{PG})$ sole, $\mathrm{T}_{2}=\mathrm{PG}+$ radish + mungbean $(1$ row at the boarder of the bed) + amaranth (broadcast), $\mathrm{T}_{3}=\mathrm{PG}+$ radish + mungbean $(2$ rows at the boarder of the bed) + shabuj shak (broadcast), $\mathrm{T}_{4}=\mathrm{PG}+$ radish + Indian spinach ( 1 row at the boarder of the bed), $\mathrm{T}_{5}=\mathrm{PG}+$ radish + Indian spinach ( 2 rows at the boarder of the bed) and $\mathrm{T}_{6}=\mathrm{PG}+$ radish + mungbean: Indian spinach $(1: 1$ row at the boarder of the bed). The fruit yield (26.27-30.50 t/ha) of pointed gourd did not affect by sole and different intercropping systems. The highest pointed gourd equivalent yield (68.02 t/ha), gross return (Tk.1020300/ha) and net return (Tk.631466/ha) and benefit cost ratio (2.62) was obtained from the intercropping combination of $\mathrm{PG}+$ radish + Indian spinach $(2$ rows at the boarder of the bed).
\end{abstract}

Keywords: Intercropping of crop species, pointed gourd, component crops.

\section{Introduction}

Pointed gourd (Trichosanthes dioica Roxb.) is an important dioecious vegetable crop belonging to the family Cucurbitaceae. Fruits are rich in vitamin and minerals and contain $9.0 \mathrm{mg} \mathrm{Mg}, 2.6 \mathrm{mg} \mathrm{Na}, 83.0 \mathrm{mg} \mathrm{K}, 1.1 \mathrm{mg} \mathrm{Cu}$, and $17.0 \mathrm{mg}$ S per 100g edible part (Singh, 1989). It has also high industrial value as different types of jam, jelly, and pickles can be made from this vegetable. Pointed gourd has a good medicinal value. It is easily digestible, diuretic, and laxative, invigorates the heart and brain and is useful in the disorder of the circulatory system (Malek., 2009). It was reported that pointed gourd possesses the medicinal property of lowering the total cholesterol and blood sugar (Chandrasekar et al., 1988; Sharma and Pant, 1988; Sharma et al., 1988). Pointed gourd is grown in the raised bed with support of trellis. Pointed gourd requires 78 months to reach its reproductive phase. In this period, farmers grow some quick vegetables (Lal sak, Indian spinach, etc.) and pulses as inter/mixed cropping with pointed gourd before reaching reproductive phase of pointed gourd at the same

${ }^{1}$ Principal Scientific Officer, Agronomy Division, Bangladesh Agricultural Research, Institute (BARI), Gazipur 1701, ${ }^{2}$ Principal Scientific Officer, Agronomy Division, BARI, RARS, Jessore, ${ }^{3}$ Senior Scientific Officer, Agronomy Division, BARI, Gazipur 1701, ${ }^{4}$ Scientific Officer, Agronomy Division, BARI, Gazipur 1701, Bangladesh. 
field. Intercropping is one of the most important, viable and profitable systems of Bangladesh. Intercropping increases total productivity through efficient utilization of inter-rows' space and different growth resources (Willey, 1979). Selection of component crops (Uddin and Satter, 1993; Bagum et al., 2010), spatial arrangement of component crops (Islam et al., 2004, Islam et al., 2006) and fertilizer management (Islam et al., 2007; Akhteruzzaman et al., 2008) are the important factors of intercropping systems for getting higher productivity. In greater Jessore area, farmers grow pointed gourd with radish and after harvest of radish, they grow Indian spinach or mungbean under the trellis of pointed gourd. But they don't follow the actual planting system as well as suitability of crop combinations for more economic return for intercropping with pointed gourd. Therefore, the experiment was undertaken to find out the suitable component crop and suitable planting system under intercropping with pointed gourd for higher productivity and profitability.

\section{Materials and Method}

The experiment was conducted at the Regional Agricultural Research Station of Bangladesh Agricultural Research Institute, Jessore during November 2008 to October 2010. The soil of the experimental field was silty clay loam in texture belonging to Calcareous Brown Flood Plain under AEZ-11. Initial soil sample was collected from experimental field and analyzed. The analytical results are presented in Table 1.

Table1. Analytical results of soil of the experimental field.

\begin{tabular}{c|c|c|c|c|c|c|c|c}
\hline $\mathrm{pH}$ & $\begin{array}{c}\text { OM } \\
(\%)\end{array}$ & $\begin{array}{c}\text { Total } \\
\mathrm{N} \\
(\%)\end{array}$ & $\begin{array}{c}\text { Avail- } \\
\text { able P } \\
(\mathrm{ppm})\end{array}$ & $\begin{array}{c}\text { Exchange - } \\
\text { able K } \\
(\mathrm{meq} / 100 \mathrm{~g})\end{array}$ & $\begin{array}{c}\text { Exchange } \\
\text {-able Ca } \\
(\mathrm{meq} / 100 \\
\mathrm{g})\end{array}$ & $\begin{array}{c}\text { Available } \\
\text { Zn (ppm) }\end{array}$ & $\begin{array}{c}\text { Available } \\
\text { S (ppm) }\end{array}$ & $\begin{array}{c}\text { Available } \\
\mathrm{B} \\
(\mathrm{ppm})\end{array}$ \\
\hline 6.6 & 1.15 & 0.061 & 35 & 14.3 & 5.7 & 1.00 & 20 & 0.60 \\
\hline
\end{tabular}

The treatment combinations were $\mathrm{T}_{1}=$ Pointed gourd (PG) as sole crop, $\mathrm{T}_{2}$ $=\mathrm{PG}+$ radish + mungbean $(1$ row at the boarder of the bed $)+$ amaranth (broadcast), $\mathrm{T}_{3}=\mathrm{PG}+$ radish + mungbean $(2$ rows at the boarder of the bed $)+$ Shabuj sak (broadcast), $\mathrm{T}_{4}=\mathrm{PG}+$ radish + Indian spinach $(1$ row at the boarder of the bed), $\mathrm{T}_{5}=\mathrm{PG}+$ radish + Indian spinach ( 2 rows at the boarder of the bed), and $\mathrm{T}_{6}=\mathrm{PG}+$ radish + mungbean : Indian spinach $(1: 1$ row at the boarder of the bed). The experiment was laid out in a randomized complete block design with three replications. The unit raised bed (trelli) size was $6.0 \mathrm{~m}$ x $1.50 \mathrm{~m}$. pointed gourd vines and radish were sown on 22 November 2008; mungbean and Indian spinach on 07 March 2009 as per treatment after harvesting of radish. Amaranth and Sabujsak were sown after harvest of 
mungbean as per treatment. Pointed gourd (var. BARI Potal-1), radish (var. Pinky), mungbean (var. BARI Mungbean-6) and local variety of Indian spinach, Amaranth, and Sabujsak were used in the experiment. Six plants of pointed gourd were planted per trelli. One male pointed gourd per 12 plants of female was grown in between two plots from proper pollination of the crop. For pointed gourd in each pit $1.0 \mathrm{~kg}$ cowdung, $250 \mathrm{~g}$ mustard oil cake, $46 \mathrm{~g}, \mathrm{~N}, 34 \mathrm{~g}$ $\mathrm{P}, 65 \mathrm{~g} \mathrm{~K}$, and $27 \mathrm{~g} \mathrm{~S}$ were applied at time of vine planting in 2008. During May-June 2009, $500 \mathrm{~g}$ cowdung, $32 \mathrm{~N}, 18 \mathrm{~g} \mathrm{P}$, and $50 \mathrm{~g} \mathrm{~K}$ were also applied in each pit of pointed gourd as ring method. All intercrops were grown with their recommended doses of fertilizers, spacing, and seed rates as sole crop. Irrigation, weeding, and other intercultural operations for pointed gourd, radish, mungbean, and Indian spinach were done as and when required.

After completion one crop cycle, the pointed gourd vines were cut at ground level on mid-September 2009 and cultivated as ratoon crop. During 01 November 2009 radish (var. Pinky) was sown again as intercrop in all treatments except sole pointed gourd. After harvest of radish, mungbean and Indian spinach were sown at the same date like previous year. The crop received total rainfall during the crop season was $1049.5 \mathrm{~mm}$ in 2008-09 and $773.1 \mathrm{~mm}$ in 2009-10 (Fig. 1).Yield component data were taken from selected 5 plants of pointed gourd and yield data of all the crops were taken from whole plot and analyzed statistically in individual year. Means were separated by LSD Test at 5\% level. Yield of component crops was converted into equivalent yield on the basis of the prevailing market price of individual crop (Bandyopadhyay, 1984).

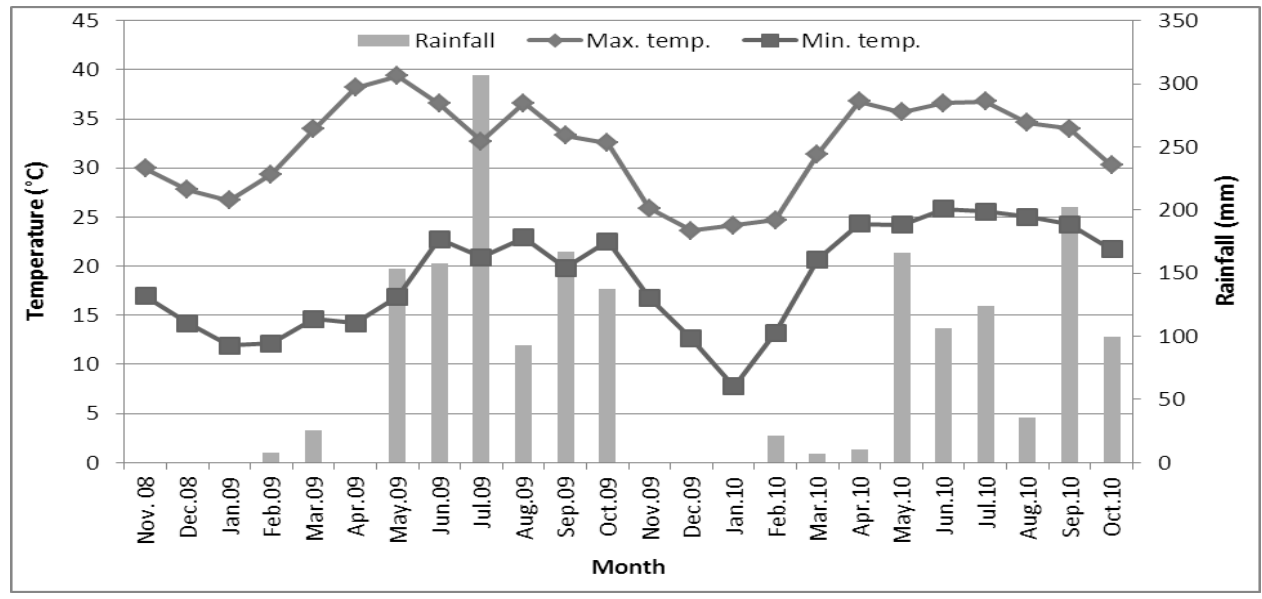

Fig. 1. Average monthly maximum, minimum temperature and monthly total rainfall during November 2008 to October 2010. 
Pointed gourd equivalent yield $(\mathrm{PEY})=\mathrm{Ysp}+\{($ Yir $\times \mathrm{Pr})+(\mathrm{Yim} \times \mathrm{Pm})+($ Yiis $\times$ Pis $)+($ Yia $\times$ Pa $)+($ Yis $\times$ Ps $)\} / P p$

Where,

Ysp = Yield of sole pointed gourd $(\mathrm{t} / \mathrm{ha})$, Yir $=$ Yield of intercrop radish $(\mathrm{t} / \mathrm{ha}), \quad$ Yia $=$ Yield of intercrop amaranth $(\mathrm{t} / \mathrm{ha}), \quad$ Yim $=$ Yield of intercrop mungbean $(\mathrm{t} / \mathrm{ha})$, Yiis $=$ Yield of intercrop Indian spinach $(\mathrm{t} / \mathrm{ha})$, Yis $=$ Yield of intercrop sabujsak $(\mathrm{t} / \mathrm{ha})$, Pis $=$ Selling price of Indian spinach, $\operatorname{Pr}=$ Selling price of radish

$\mathrm{Pa}=$ Selling price of amaranth, $\mathrm{Ps}=$ Selling price of sabujsak, $\mathrm{Pm}=$ Selling price of mungbean

\section{Relative yield calculated as follows}

Relative yield $(\mathrm{RY})=\mathrm{Yip} / \mathrm{Ysp}$

Where, $\mathrm{Ysp}=$ Pointed gourd sole yield $(\mathrm{t} / \mathrm{ha})$ and $\mathrm{Yip}=$ Yield of pointed gourd in intercrops ( $\mathrm{t} / \mathrm{ha}$ ) Market prices of all crops were recorded during their harvesting time. Gross return, cost of cultivation and net return (Tk./ha) was computed from sole and intercropping systems per hectare basis. The results obtained for two years were almost similar, hence the data were pooled.

Table 2. Yield component and yield of pointed gourd and intercrops (Pooled data of 2008-10).

\begin{tabular}{l|c|c|c|c|c|c}
\hline \multirow{2}{*}{ Treatments } & \multicolumn{3}{|c|}{ Pointed gourd } & \multicolumn{3}{c}{ Intercrops (t/ha) } \\
\cline { 2 - 7 } & $\begin{array}{c}\text { Fruits/plant } \\
\text { (no.) }\end{array}$ & $\begin{array}{c}\text { Wt of } \\
\text { fruits/plant } \\
(\mathrm{kg})\end{array}$ & $\begin{array}{c}\text { Fruit } \\
\text { yield } \\
(\mathrm{t} / \mathrm{ha})\end{array}$ & $\begin{array}{c}\text { Root } \\
\text { yield of } \\
\text { radish }\end{array}$ & $\begin{array}{c}\text { Seed yield } \\
\text { of } \\
\text { mungbean }\end{array}$ & $\begin{array}{c}\text { Biomass } \\
\text { yield of } \\
\text { leafy } \\
\text { vegetables }\end{array}$ \\
\hline $\mathrm{T}_{1}$ & 115 & 6.78 & 30.50 & - & - & - \\
$\mathrm{T}_{2}$ & 113 & 6.62 & 29.61 & 41.70 & 0.36 & 11.43 \\
$\mathrm{~T}_{3}$ & 102 & 5.98 & 26.86 & 41.76 & 0.49 & 6.93 \\
$\mathrm{~T}_{4}$ & 113 & 6.53 & 29.44 & 43.84 & - & 66.81 \\
$\mathrm{~T}_{5}$ & 101 & 5.90 & 26.27 & 42.86 & - & 82.94 \\
$\mathrm{~T}_{6}$ & 103 & 5.95 & 26.80 & 42.59 & 0.42 & 61.16 \\
\hline $\mathrm{CV}(\%)$ & 8.87 & 10.35 & 10.41 & 9.10 & 5.62 & 5.20 \\
$\mathrm{LSD}_{(0.05)}$ & $\mathrm{NS}$ & $\mathrm{NS}$ & $\mathrm{NS}$ & $\mathrm{NS}$ & 0.72 & 4.49 \\
\hline
\end{tabular}

$\mathrm{NS}=$ Not significant 


\section{Results and Discussion}

\section{Fruit yield and yield attributes of pointed gourd in sole and intercrop combinations}

Number of fruits/plant, fruit weight per plant, and fruit yield/ha of pointed gourd are presented in Table 2. Fruit yield and yield components of pointed gourd was not affected significantly by different intercropping systems. The results showed that the companion crops did not influence the yield of pointed gourd in the intercropping systems. Sole pointed gourd showed slightly higher yield than intercropped. Minimum yield reduction (1.0 t/ha) of pointed gourd was observed in $\mathrm{T}_{5}$ treatment and others were similar with yield reduction of about $3.0 \mathrm{t} / \mathrm{ha}$.

\section{Yield of intercrops}

Root yield of radish was not significantly influenced by different treatments but seed yield of mungbean was significantly affected (Table 2). Treatment $\mathrm{T}_{3}$ showed highest seed yield (0.49 t/ha) of mungbean as compared to $\mathrm{T}_{2}$ and $\mathrm{T}_{6}$ treatments, respectively. Biomass yield of leafy vegetables also differed significantly where treatment $\mathrm{T}_{5}$ (Indian spinach) produced higher yield. Indian spinach gave much higher biomass yield than amaranth. Though treatment $T_{5}$ showed much higher biomass yield but pointed gourd yield was reduced as compared to $\mathrm{T}_{4}$ treatment.

Table 3. Pointed gourd equivalent yield (PEY), relative yield, cost and benefit analysis of different treatment (Pooled).

\begin{tabular}{l|c|c|c|c|c|c}
\hline Treatments & PEY (t/ha) & $\begin{array}{c}\text { Relative } \\
\text { yield }\end{array}$ & $\begin{array}{c}\text { Gross } \\
\text { return } \\
\text { (Tk./ha) }\end{array}$ & $\begin{array}{c}\text { Cost of } \\
\text { cultivation } \\
\text { (Tk./ha) }\end{array}$ & $\begin{array}{c}\text { Net return } \\
\text { (Tk./ha) }\end{array}$ & $\begin{array}{c}\text { Benefit } \\
\text { cost ratio }\end{array}$ \\
\hline $\mathrm{T}_{1}$ & 30.50 & 1.00 & 457500 & 276610 & 180890 & 1.65 \\
$\mathrm{~T}_{2}$ & 45.49 & 0.97 & 682350 & 301055 & 381295 & 2.27 \\
$\mathrm{~T}_{3}$ & 45.12 & 0.88 & 676800 & 312166 & 364634 & 2.17 \\
$\mathrm{~T}_{4}$ & 64.93 & 0.97 & 973950 & 372433 & 601517 & 2.61 \\
$\mathrm{~T}_{5}$ & 68.02 & 0.86 & 1020300 & 388834 & 631466 & 2.62 \\
$\mathrm{~T}_{6}$ & 61.44 & 0.88 & 921600 & 354388 & 567212 & 2.60 \\
\hline
\end{tabular}

$\mathrm{T}_{1}=$ Pointed gourd $(\mathrm{PG})$ sole

$\mathrm{T}_{2}=\mathrm{PG}+$ radish + mungbean $(1$ row at the boarder of the bed) + amaranth (broadcast)

$\mathrm{T}_{3}=\mathrm{PG}+$ radish + mungbean $(2$ rows at the boarder of the bed) + shabuj sak (broadcast)

$\mathrm{T}_{4}=\mathrm{PG}+$ radish + Indian spinach $(1$ row at the boarder of the bed)

$\mathrm{T}_{5}=\mathrm{PG}+$ radish + Indian spinach $(2$ rows at the boarder of the bed) and

$\mathrm{T}_{6}=\mathrm{PG}+$ radish + mungbean $:$ Indian spinach $(1: 1$ row at the boarder of the bed)
Price:

Pointed gourd $(\mathrm{PG})=$ Tk.15.00 per kg

Radish

$=\mathrm{Tk} .3 .00$ per $\mathrm{kg}$

Mungbean

$=\mathrm{Tk} .60 .00$ per $\mathrm{kg}$

Indian spinach

$=$ Tk. 6.00 per $\mathrm{kg}$

Amaranth/Shabuj Shak $=$ Tk.8 .00 per kg 


\section{Pointed gourd equivalent (PEY), relative yield, and economic evaluation}

The equivalent yield of pointed gourd was influenced markedly in response to different component crops (Table 3 ). The highest pointed gourd equivalent yield (PEY) was obtained from the treatment $\mathrm{T}_{5}(68.02 \mathrm{t} / \mathrm{ha})$ followed by that in $\mathrm{T}_{4}$ (64.93 t/ha) and $\mathrm{T}_{6}(61.44 \mathrm{t} / \mathrm{ha})$ treatment, while $\mathrm{T}_{1}, \mathrm{~T}_{2}$ and $\mathrm{T}_{3}$ treatment gave the lowest PEY. Higher pointed gourd equivalent yield was recorded from all the intercropping treatments. Such yield advantages could be due to combined yield of pointed gourd and component crops. Higher equivalent yields were also reported by Ahmed et al. (2010) and Mahfuza et al. (2012) in intercropping systems compared to sole crop. The relative yields of intercropped ranged from 0.86 to 0.97 depending upon the different planting systems. The minimum yield reduction (3\%) of pointed gourd was recorded from the $\mathrm{T}_{2}$ and $\mathrm{T}_{4}$ treatments and others ranged from $12-14 \%$. Cost and return analysis of intercropping of different component crops with pointed gourd are presented in Table 2 . The highest gross return (Tk. 1020300/ha) and net return (Tk. 631466/ha) obtained from $\mathrm{T}_{5}$ treatment. Sole pointed gourd gave the lowest gross return (Tk. 457500/ha) and net return (Tk. 180890/ha). Net return was higher under intercropping systems than that of sole pointed gourd. The cost of cultivation was highest under intercropping systems, particularly in $\mathrm{T}_{5}$ treatment which was mainly due to more expenditure for purchase of seedling of Indian spinach. Maximum benefit cost ratio (2.62) was also obtained from $T_{5}$ treatment followed by that of $T_{4}$ and $T_{6}$ treatments.

\section{Conclusion}

It appears from the results that radish, mungbean, Indian spinach, amranth, and Sabuj shak could be grown as intercrop with pointed gourd. However, pointed gourd + radish +2 rows of Indian spinach at the boarder of the bed followed by pointed gourd + radish +1 or 2 rows of Indian spinach at the boarder of the bed was found most productive and profitable.

\section{References}

Ahmed, I. M., M. N. Islam, B. L. Nag, M. A. I. Sarker, M. T. Rahaman and U. A Nadira. 2010. Intercropping of grasspea and field pea as vegetable and fodder with hybrid maize. Eco-friandly Agril. J. 3(6): 298-301.

Akhteruzzaman, M., M. N Islam, B. L. Nag and M. T. Rahman. 2008. Productivity of potato-hybrid maize relay cropping under different fertilizer levels. Eco-friandly Agril. J. 1(5): 300-303.

Bandyopadhyay, S. N. 1984. Nitrogen and water relations in grain sorghum-legume intercropping systems. Ph. D. Dissertation, Indian Agricultural Research Institute, New Delhi. 
Begum, S., S. S. Kakon, M. N Islam, F.Ahmed and M. M. Haque. 2010. Study on intercropping different spices with hybrid maize. J. Expt. Biosci. 1(2): 47-50.

Chandrasekar, B., B Mukherjee and S. K. Mukherjee. 1988. Blood sugar powering the effect of (Trichosanthes dioica Roxb.) In experimental rat models. Int. J. Crude Drug Res. 26:102-106.

Islam, M. N., M. A. Hossain, M. S. A. Khan, B. L. Nag, M. A. I. Sarker, M. T. Rahman and I. M. Ahmed. 2007. Fertilizer management in hybrid maize-sweet potato intercropping systems. Bangladesh J. Crop Sci. 18(1): 89-94.

Islam. M. N., M. M. Haque and A. Hamid. 2006. Planting arrangement and population density effects on the physiological attributes and productivity of maize-bushbean intercropping systems. Bangladesh J. Agril. Res. 31(3): 353-364.

Islam. M. N., M. M. Haque and A. Hamid. 2004. Spatial arrangement and population density effect on productivity of maize-bushbean intercropping systems. Bangladesh J. Agril. Res. 29(3): 467-474.

Mahfuza, S.N., M. N. Islam, A. Hannan, M. Akteruzzaman and S. Begum. 2012. Intercropping different vegetables and spices with pointed gourd. J. Expt. Biosci. 3(1): 77-82

Malek, M. A. 2009. In vitro propagation of pointed gourd (Trichosanthes dioica Roxb.) through encapsulated shoot tips. Bangladesh J. Agril. Res. 34 (4): 555-563.

Sharma, G and M. C. Pant. 1988. Effects of feeding Trichosanthes dioica (Parval) on blood glucose, serum triglyceride, phospholipids, cholesterol and density lipoproteincholesterol levels in the normal albino rabbit. Current Sci. 57: 1085-1087.

Sharma, G., M.C Pant and G. Sharma. 1988. Preliminary observations on serum biochemical parameters of albino rabbits fed on Trichosanthes dioica (Roxb). Indian J. Medical Res. 87: 398-400.

Singh, K. 1989. Pointed gourd (Trichosanthes dioica Roxb.) Indian Hort. 33: 35-38.

Uddin, M. S. and M. A. Satter. 1993. Prospects of intercropping maize with legumes and vegetables in hill tracts. Bangladesh J. Agril. Res. 18 (2): 227-230.

Willey, R.W. 1979. Intercropping its importance and research needs. Pant I. Competition and yield advantages. Field Crops Abst. 32 (1) 1-10. 